\title{
AKUNTABILITAS DAN TRANSPARANSI PENGELOLAAN KEUANGAN PANTI ASUHAN (STUDI PADA PSAA UDYANA WIGUNA SINGARAJA) TAHUN 2016
}

\author{
Luh Gede Ria Utami Agustin \\ Jurusan Pendidikan Ekonomi, Fakultas Ekonomi \\ Universitas Pendidikan Ganesha Singaraja, \\ Indonesia \\ email : odtheyrhya1@gmail.com
}

\begin{abstract}
Abstrak
Penelitian ini bertujuan untuk mengetahui proses perolehan dana, pengelolaan dana dan proses pertanggungjawaban yang dilakukan oleh Panti Sosial Asuhan Anak Udyana Wiguna Singaraja untuk menjaga transparansi dan akuntabilitas pengelolaan keuangan. Penelitian ini adalah penelitian deskriptif dengan pendekatan kualitatif. Data diperoleh dengan melakukan observasi awal, wawancara, dan dokumentasi. Metode analisis data yang digunakan adalah metode analisis deskriptif kualitatif. Hasil penelitian menunjukkan bahwa, proses perolehan dana dimulai dari proses penyusunan rancangan kerja anggaran oleh staf panti yang dikirimkan kepada Dinas Sosial hingga memperoleh dokumen pelaksanaan anggaran, pengelolaan keuangan di panti dilaksanakan dengan berpedoman pada dokumen pelaksanaan anggaran yang diberikan oleh Dinas Sosial, dan Panti Sosial Asuhan Anak Udyana Wiguna Singaraja membuat rancangan kerja anggaran yang disusun dalam sebuah rapat antara staf panti dan juga surat pertanggungjawaban penggunaan dana sesuai dokumen pelaksanaan anggaran sebagai bentuk pertanggungjawaban pengelolaan keuangan.
\end{abstract}

Kata Kunci : akuntabilitas, pengelolaan keuangan, transparansi

\begin{abstract}
This research aims to determine the process of obtaining funds, fund management and the accountability process undertaken by Udyana Wiguna Singaraja Social Child Orphanage to maintain transparency and accountability of financial management. This research is descriptive research with qualitative approach. Data were obtained by conducting preliminary observations, interviews, and documentation. Data analysis method used is descriptive qualitative analysis method. The results showed that the process of obtaining funds starts from the process of drafting the budget work plan by the orphanage staff sent to the Social Service to obtain budget implementation documents, financial management in the Udyana Wiguna Singaraja Social Child Orphanage follows the budget execution document provided by the Social Service, and Udyana Wiguna Singaraja social child orphanage make a budget work plan arranged in a meeting between the orphanage staff and also the letter of accountability of the use of funds according to the budget execution document as a form of financial management accountability.
\end{abstract}

Keyword: accountability, financial management, transparency

\section{PENDAHULUAN}

Ada banyak jenis organisasi yang ada di Indonesia salah satunya adalah organisasi nirlaba. "organisasi nirlaba adalah organisasi yang dapat dimiliki pemerintah maupun dimiliki oleh sektor swasta, tujuan utamanya tidak semata- mata untuk mendapatkan keuntungan" (Sujarweni,2015:215). Karakteristik organisasi nirlaba berbeda dengan organisasi bisnis. Perbedaan utama yang mendasar terletak pada cara organisasi memperoleh daya yang dibutuhkan untuk melakukan berbagai 
aktivitas operasinya. Menurut PSAK No.

45 bahwa "organisasi nirlaba memperoleh sumber daya dari sumbangan para anggota dan para penyumbang lain yang tidak mengharapkan imbalan apapun dari organisasi tersebut". (Ikatan Akuntan Indonesia, 2004:45).

Salah satu bentuk organisasi nirlaba di Indonesia adalah panti asuhan. Departemen Sosial RI (2004:4) menyatakan panti sosial asuhan anak adalah suatu lembaga kesejahteraan sosial yang mempunyai tanggung jawab untuk memberikan pelayan kesejahteraan sosial pada anak terlantar dan melaksanakan penyantunan dan pengentasan anak terlantar, memberikan pelayanan pengganti orang tua/wali anak dalam memenuhi kebutuhan fisik, mental dan sosial kepada anak asuh sehingga memperoleh kesempatan yang luas, tempat dan memadai bagi pengembangan kepribadiannya sesuai dengan yang diharapkan sebagai bagian dari penerus cita-cita bangsa dan sebagai insan yang akan turut serta aktif dalam bidang pembangunan nasional.

Panti asuhan anak adalah proyek pelayanan dan penyantunan terhadap anak-anak yatim, yatim piatu, keluarga retak, dan anak terlantar dengan cara memenuhi segala kebutuhan, baik berupa material maupun spiritual, yang meliputi: sandang pangan, papan, pendidikan, kesehatan. Dalam beberapa keadaan tertentu keluarga tak dapat menjalankan fungsinya dengan baik dalam pemenuhan kebutuhan anak yang kemudian menyebabkan ketelantaran pada anak.

Beberapa penyebab ketelantaran anak adalah sebagai berikut. 1) Orang tua meninggal dan atau tidak ada sanak keluarga yang merawatnya sehingga anak menjadi yatim piatu. 2) Orang tua tidak mampu (sangat miskin) sehingga tidak dapat memenuhi kebutuhan minimal anak-anaknya. 3) Orang tua tidak dapat dan tidak sanggup melaksanakan fungsinya dengan baik atau dengan wajar dalam waktu relatif lama misalnya menderita penyakit

Ada berbagai sumber pendapatan, baik itu di perusahaan swasta maupun instansi sektor publik. Untuk di perusahaan swasta pendapatan berasal dari penjualan barang atau jasa, sumbangan dari donatur, dan pinjaman, sedangkan untuk instansi sektor publik pendapatan dapat berasal dari pajak, retribusi, hibah, bantuan, dan dana bagi hasil. Akan tetapi adapula istilah sumber pendapatan regular dan non regular.

Pendapatan regular merupakan pendapatan yang berasal dari usaha suatu instansi baik swasta maupun pemerintah, sedangkan pendapatan non regular adalah pendapatan yang berasal dari luar usaha instansi, baik itu berupa hibah, maupun sumbangan atau bantuan. Untuk mengetahui jumlah pendapatan yang dihasilkan dan jumlah biaya yang dikeluarkan oleh organisasi maka perlu pula dibuat laporan keuangan.

Dalam hal pengelolaan keuangan, para donatur biasanya mensyaratkan adanya pelaporan sebagai bentuk pertanggungjawaban pengelola organisasi nirlaba atas dana yang diberikan. Dalam mengelola suatu keuangan, tentu saja ada kemungkinan untuk terjadi manipulasi data, sehingga masyarakat yang tidak memahami tentang pengelolaan keuangan mudah ditipu oleh penerima amanah.

Laporan keuangan juga menjadi suatu hal yang sangat penting untuk diberikan kepada pemberi amanah, karena melalui laporan keuangan, pemberi amanah dapat mengetahui posisi keuangan organisasi dan para anggota dan donatur tersebut ingin mengetahui dana yang mereka berikan apakah sudah dikelola dengan baik dan apakah dapat bermanfaat bagi kepentingan publik sesuai dengan prinsip akuntabilitas dan transparansi.

Di masa ini transparansi dan akuntabilitas menjadi hal yang sangat penting bagi pengelolaan keuangan setiap organisasi, baik organisasi 
pemerintahan

maupun

non

pemerintahan.

Prinsip akuntabilitas publik adalah suatu ukuran yang menunjukkan seberapa besar tingkat kesesuaian penyelenggaraan pelayanan dengan ukuran nilai-nilai atau norma-norma eksternal yang dimiliki oleh para stakeholder yang berkepentingan dengan pelayanan tersebut.

Akuntabilitas publik mengandung kewajiban menurut undang-undang untuk melayani atau memfasilitasi pengamat atau pemerhati independen yang memiliki hak untuk melaporkan temuan atau informasi mengenai administrasi keuangan yang tersedia sesuai dengan permintaan tingkat tinggi pemerintah. Mardiasmo (2009) menyatakan transparansi dan akuntabilitas menjadi kewajiban dan tanggungjawab pemegang amanah untuk mengelola, menyajikan, melaporkan serta menyampaikan segala aktivitas yang dilaksanakan kepada pemberi amanah, dimana pemberi amanah tentunya memiliki hak dan kewenangan untuk meminta pertanggungjawaban tersebut.

Akuntabilitas merupakan suatu pertanggungjawaban dari seseorang/badan yang sangat penting bagi pihak-pihak yang terlibat atau berkepentingan. Karena dengan adanya akuntabilitas yang baik, berarti kewajiban dari akuntan telah terlaksana. Menurut Siahaan (2012) akuntabilitas adalah kewajiban untuk memberikan pertanggungjawaban dan menerangkan kinerja dan tindakan seseorang/badan hukum/pemimpin suatu organisasi kepada pihak yang memiliki hak atau berkewenangan untuk meminta keterangan atau pertanggungjawaban, meliputi keberhasilan maupun kegagalan pelaksanaan misi instansi yang bersangkutan. Artinya setiap instansi pemerintah mempunyai kewajiban untuk mempertanggungjawabkan pengelolaan sumber daya yang dipercayakan kepadanya, mulai dari tahap perencanaan, implementasi, sampai dengan pertanggungjawaban, kejelasan fungsi, pelaksanaan da pertanggungjawaban, pengelolaan perusahaan/instansi secara efisien da efektif. Akuntabilitas dapat diartikan sebagai bentuk kewajiban mempertanggungjawabkan

keberhasilan atau kegagalan pelaksanaan misi organisasi dalam mencapai tujuan dan sasaran yang telah ditetapkan sebelumnya, melalui suatu media pertanggungjawaban yang telah ditetapkan secara periodik.

Menurut Silvia dan Ansar (2001) akuntabilitas memiliki berbagai dimensi. Dimensi pertama adalah akuntabilitas kejujuran dan hukum terkait dengan dilakukannya penyalahgunaan, KKN (Korupsi Kolusi Nepotisme), sehingga dapat menjamin sebuah praktek yang sehat, sedangkan akuntabilitas hukum menjamin adanya peraturan terkait dengan supremasi hukum dan peraturan lain dalam organisasi. Kedua, akuntabilitas proses menjelaskan bagaimana prosedur yang digunakan dalam melaksanakan tugas, hal ini ditekankan lebih kepada pemberian layanan yang cepat dan responsif. Ketiga, akuntabilitas program berkaitan dengan bagaimana organisasi melahirkan sebuah program yang berkualitas serta mendukung strategi dalam pencapaian visi misi organisasi. Keempat, akuntabilitas kebijakan maksud dari penjelasan ini yaitu terkait dengan pertanggungjawaban yang dilakukan pembina, pengurus dan pengawas atas kebijakan yang diambil, sehingga dibutuhkan sebuah pertimbangan dalam membuat suatu kebijakan. Kelima, akuntabilitas finansial adalah pertanggungjawaban suatu lembaga dalam menggunakan dana secara ekonomis, efisien dan efektif.

"Transparansi merupakan keterbukaan organisasi untuk menyediakan informasi yang relevan dengan cara yang mudah diakses dan dipahami oleh pemangku kepentingan" (Atmaja,dkk, 2013:19). Menurut United Natoins Development Program (UNDP) (dalam Mardiasmo, 2009) Transparansi adalah adanya kebijakan terbuka bagi 
pengawasan. Sedangkan yang dimaksud dengan informasi adalah informasi mengenai setiap aspek kebijakan pemerintah yang dapat dijangkau publik. Keterbukaan informasi diharapkan akan menghasilkan persaingan politik yang sehat, kebijakan dibuat berdasarkan preferensi publik.

Menurut

Siahaan

(2012)

transparansi adalah keterbukaan dalam melaksanakan proses pengambilan keputusan dan keterbukaan dalam mengemukakan informasi material dan relevan mengenai instansi yang bersangkutan, terbukanya akses bagi semua pihak yang berkepentingan terhadap setiap informasi pengelolaan keuangan negara. Artinya dalam pengelolaan keuangan negara tidak ada yang disembunyikan, semua secara terbuka. Keterbukaan ini mencakup mulai dari kegiatan perencanaan anggaran sampai dengan pertanggungjawabannya. Transparansi dibangun atas dasar arus informasi yang bebas. Seluruh proses pemerintahan, lembaga-lembaga dan informasi perlu dapat diakses oleh pihak yang berkepentingan, dan informasi yang tersedia harus memadai agar dapat dimengerti dan dipantau.

Namun transparansi menurut Ratminto (dalam Anggraini, 2013), bahwa transparansi dalam penyelenggaraan pelayanan publik adalah terbuka, mudah dan dapat diakses oleh semua pihak yang membutuhkan secara memadai dan mudah dimengerti. Keterbukaan yang dimaksud adalah dimana seluruh informasi perlu dan dapat diakses oleh pihak-pihak yang berkepentingan, serta informasi yang tersedia harus memadai agar dapat dimengerti dan dipantau oleh pihak-pihak yang berkaitan.

Dwiyanto (2006:80) mendefinisikan "transparansi sebagai penyediaan informasi tentang pemerintahan bagi publik dan dijaminnya kemudahan di dalam memperoleh informasi-informasi yang akurat dan memadai".

Dari pengertian tersebut dijelaskan bahwa transparansi tidak hanya sekedar menyediakan informasi tentang penyelenggaraan pelayanan

pemerintahan, namun harus disertai dengan kemudahan akses bagi masyarakat untuk memperoleh informasi dan memahami informasi yang diberikan tersebut.

Dwiyanto (2006) mengemukakan ada tiga indikator transparasi yang dapat digunakan. Indikator pertama adalah mengukur tingkat keterbukaan pelayanan publik disini meliputi seluruh proses pelayanan publik, termasuk didalamnya adalah persyaratan, biaya dan waktu yang dibutuhkan untuk sebuah pelayanan publik, serta tata cara dalam proses pelayanan publik. Persyaratan yang harus dipenuhi harus terbuka dan mudah diketahui oleh para pengguna atau stakeholder lain. Penyelenggaraan pelayanan harus berusaha menjelaskan kepada para pengguna mengenai persyaratan yang harus dipenuhi berserta alasan diperlukannya persyaratan itu dalam proses pelayanan publik.

Indikator yang kedua dari transparasi menunjuk kepada seberapa mudah peraturan dan prosedur pelayanan yang dapat dipahami oleh pengguna dan stakeholder yang lain. Maksud dipahami disini bukan hanya dalam arti literal semata tetapi juga makna dibalik semua prosedur dan peraturan itu. Penjelasan mengenai persyaratan, prosedur, biaya dan waktu yang diperlukan untuk sebuah pelayanan sebagaimana adanya merupakan hal yang paling penting bagi para pengguna. Jika rasionalitas dari semua hal itu dapat diketahui dan diterima oleh para pengguna, maka kepatuhan terhadap prosedur dan aturan akan mudah diwujudkan dan dipahami dalam proses penyelenggaraan publik.

Indikator ketiga dari transparansi adalah kemudahan untuk memperoleh informasi mengenai berbagai aspek yang berkaitan dengan seluruh proses dalam penyelenggaraan pelayanan publik. Semakin mudah pengguna dan memperoleh informasi mengenai berbagai aspek penyelenggaran pelayanan publik maka semakin tinggi 
transparasi dari pelayanan publik yang bersangkutan. Misalnya, ketika pengguna dengan mudah memperoleh informasi mengenai biaya dan waktu yang diperlukan untuk menyelesaikan pelayanan maka pelayanan publik itu dapat dinilai memiliki transparansi yang tinggi.

Krina (2003) menyebutkan beberapa alat-alat ukur transparansi, yaitu sebagai berikut. 1) Publikasi kebijakan publik melalui alat-alat komunikasi, yaitu annual reports, brosur, leaflet, pusat informasi, telepon bebas pulsa, liputan media, iklan layanan masyarakat, website, papan pengumuman, koran lokal. 2) informasi yang disajikan, yaitu acuan pelayanan, perawatan data, laporan kegiatan publik, prosedur keluhan.

penanganan keluhan, yaitu berita-berita kota di media massa dan lokal, notice of respon, limit waktu respon, opinion pools \& survey tentang isu-isu kebijakan publik, komentar \& catatan untuk draft kebijakan \& peraturan, service users surveys. 4) institusi dan organisasi daerah, yaitu Bawasda, kantor PMD/BPM, kantor Humas, dinas Kominfo, Forum Lintas Pelaku. 5) Pertemuan masyarakat. 6) Mimbar rakyat.

Panti Sosial Asuhan Anak Udyana Wiguna Singaraja merupakan salah satu panti asuhan yang didirikan oleh pemerintah melalui UPT Pelayanan Sosial Provinsi Bali. Selain mendapat dana dari donatur, panti ini juga memperoleh dana dari pemerintah Sebagai suatu lembaga yang memperoleh dana dari pemerintah dan donatur, maka penting bagi panti asuhan untuk menjaga transparansi dan akuntabilitas pengelolaan keuangannya sebagai bentuk pertanggungjawaban keuangan panti kepada pemerintah.

Adapun tujuan dari penelitian yang dilakukan adalah untuk menggambarkan proses perolehan dana pada PSAA Udyana Wiguna Singaraja, untuk menggambarkan manajemen pengelolaan dana pada PSAA Udyana Wiguna Singaraja, dan untuk mengetahui proses pertanggungjawaban yang dilakukan oleh PSAA Udyana Wiguna Singaraja untuk menjaga akuntabilitas dan transparansi

\section{METODE}

Penelitian ini menggunakan metode pendekatan kualitatif, dimana peneliti akan melakukan observasi langsung ke lapangan dan mengumpulkan dana yang dianalisis berdasarkan pengamatan dan pengetahuan peneliti. Penelitian ini dilakukan pada objek yang alamiah yaitu objek yang berkembang apa adanya yaitu akuntabilitas pengelolaan keuangan pada PSAA Udyana Wiguna Singaraja. Adapun dalam penelitian ini peneliti berupaya untuk melakukan penelitian sebagaimana kaidah-kaidah penelitian kualitatif.

Data dalam penelitian ini ada 2 yaitu data primer dan data sekunder. Data primer berupa hasil wawancara dengan staf panti. Data sekunder berupa dokumen-dokumen yang menunjang hasil penelitian. Teknik pengumpulan data dalam penelitian ini yaitu observasi, wawancara, dan dokumentasi. Teknik analisis data yang digunakan dalam penelitian ini adalah tehnik analisis data deskriptif kualitatif. Metode analisis data deskriptif kualitatif dalam suatu penelitian berguna untuk mengembangkan teori yang telah dibangun dari data yang sudah didapatkan di lapangan dengan tahapan sebagai berikut. Reduksi data, penyajian data, analisis data dan penarikan kesimpulan. Setelah analisis data selanjutnya akan dilakukan pengujian keabsahan data dengan trianggulasi data yang meliputi trianggulasi metode, trianggulasi sumber, trianggulasi situasi dan trianggulasi teori.

\section{HASIL DAN PEMBAHASAN Hasil}

Berdasarkan hasil penelitian proses perolehan dana pada PSAA Udyana Wiguna Singaraja dimulai dari proses perencanaan yang dilaksanakan pada bulan Januari. Pada proses ini staf panti 
akan mengadakan rapat untuk menganalisis kebutuhan anak selama 1 tahun kedepan. Dalam rapat ini, masing-masing staf akan menganggarkan biaya untuk kebutuhan anak asuh sesuai dengan tugasnya misalnya untuk biaya pendidikan, pakaian, makanan, dll.

Setelah seluruh biaya diakumulasikan maka tersusunlah Rancangan Kerja Anggaran (RKA). RKA yang disusun tidak banyak mengalami perubahan dari tahun-tahun sebelumnya kecuali mendapat intruksi dari Dinas Sosial untuk menaikkan nominal RKA tersebut. RKA yang disusun oleh staf panti biasanya akan selesai dikerjakan pada bulan April.

RKA yang telah disusun akan dikirim ke UPT Pelayanan Sosial Provinsi Bali untuk selanjutnya diteruskan ke Dinas Sosial Provinsi Bali. RKA yang telah diterima oleh Dinas Sosial Provinsi Bali akan ditindaklanjuti dengan diadakannya sidang antara staf Dinas Sosial dan staf PSAA Udyana Wiguna Singaraja untuk membahas mengenai RKA yang telah disusun. Masing-masing rekening yang terdapat dalam RKA akan dibahas untuk mengetahui kebermanfaatannya yang disesuaikan dengan Peraturan Gubernur Bali No. 30 Tahun 2013 tentang Dokumen Pelaksanaan Anggaran Dinas Sosial Provinsi Bali Tahun Anggaran 2013. Rekening yang sesuai dengan Pergub akan diterima, akan tetapi rekening yang tidak sesuai dengan Pergub akan direvisi oleh Dinas Sosial.

RKA yang telah disepakati akan diserahkan kepada Biro Keuangan untuk selanjutnya staf panti akan diberikan Dokumen Pelaksanaan Anggaran sebagai pedoman untuk pelaksanaan pengelolaan keuangan di panti.

Pengelolaan keuangan di PSAA Udyana Wiguna Singaraja dilaksanakan dengan staf yang mengurus DPA mengalokasikan dana yang telah diberikan untuk kebutuhan-kebutuhan yang ada dalam panti selama 1 tahun. Adapun pengalokasian tersebut meliputi pembayaran honorarium, pembelian barang dan jasa habis pakai, pembelian obat-obatan P3K, pembelian keperluan kantor, pembayaran pengandaan/ percetakan, pembayaran sewa kendaraan, biaya untuk melaksanakan rapat, pembelian pakaian anak asuh, biaya perjalanan dinas dan biaya pendidikan untuk anak asuh.

Pembayaran honorarium untuk pegawai honorer dialokasikan sebanyak $20,89 \%$ yang terdiri dari 2 orang penjaga malam dan 3 orang juru masak. Pembayaran honorarium ini juga termasuk pembayaran BPJS kesehatan dan ketenagakerjaan.

Pembayaran barang dan jasa habis pakai dialokasikan sebanyak 49,07\% yang terdiri dari pembelian alat-alat tulis untuk keperluan anak asuh, pembelian materai untuk administrasi pendidikan anak asuh dan administrasi kantor, pembelian tabung gas untuk memasak dan pembelian bahan-bahan kebutuhan pokok untuk konsumsi anak asuh selama tinggal di panti dalam kurun waktu 1 tahun kedepan. Pembelian obat-obatan dialokasikan sebesar $0,79 \%$ yang meliputi obat-obatan yang dibutuhkan anak panti sesuai dengan musim yang ada dan juga obat-obatan P3K.

Belanja jasa kantor yang dimaksud adalah biaya untuk cetak foto bagi anak asuh yang menjadi siswa baru di sekolah yang tentunya membutuhkan foto sebagai syarat administrasi yang dialokasikan sebesar 0,03\%. Belanja cetak dan penggandaan untuk keperluan administrasi kantor dan danak asuh dialokasikan sebesar 0,02\%.

Panti ini biasanya mengadakan kegiatan keagamaan rutin setiap tahunnya bagi anak asuh berupa adanya tirta yatra yang tentunya memerlukan alat transportasi berupa bis sebagai sarana transportasi yang dialokasikan sebesar 1,19\%. Selain kegiatan keagamaan, staf panti juga melaksanakan rapat rutin setiap triwulan untuk membahas mengenai pengelolaan keuangan yang telah dilaksanakan selama kurun waktu 3 
bulan sebelumnya. Biaya yang dibutuhkan untuk melaksanakan rapat ini dialokasikan sebesar 1,88\%.

Setiap tahun tentunya anak asuh membutuhkan pakaian untuk dapat digunakan baik itu seragam sekolah, olahraga maupun pakaian untuk sembahyang. Staf panti mengalokasikan dana sebesar 9,22\% untuk pakaian anak asuh. Anak asuh yang sudah melewati masa Sekolah Menengah Atas akan meninggalkan panti karena sudah dianggap dewasa untuk hidup mandiri, hal ini menyebabkan setiap tahunnya akan ada anak asuh baru yang akan tinggal di panti. Sebelum diperbolehkan untuk tinggal di panti, anak yang menjadi calon anak asuh akan melalui proses seleksi terlebih dahulu. Oleh karena itu dialokasikan biaya untuk perjalanan seleksi anak asuh dan perjalanan dinas untuk staf panti sebanyak $1,45 \%$.

Biaya pendidikan anak asuh dialokasikan sebesar $15,46 \%$ yang meliputi biaya pendidikan untuk masuk sekolah baru tahun ajaran 2016 untuk jenjang SMP dan SMA/SMK da pembayaran iuran komite untuk SMP dan SMA/SMK. Masing-masing staf yang mengurus sebuah rekening yang bmenangani kebutuhan anak panti akan bertanggungjawab kepada staf yang mengurus DPA di panti.

Proses pertanggungjawaban pengelolaan keuangan untuk menjaga akuntabilitas di panti asuhan dapat dilihat dari perencanaan dan penyususunan RKA yang dilaksanakan dalam sebuah rapat antara staf panti yang masing-masing mempunyai tugas yang berbeda dalam melaksanakan tugas dalam panti misal staf yang mengurus makanan anak, sekolah anak dll. Dalam rapat ini masing-masing staf akan mengusulkan biaya yang diperlukan untuk anak dalam kurun waktu 1 tahun sesuai dengan bidang yang dikerjakannya. Dari masingmasing anggaran biaya tersebut akan dikumpulkan dan disusun menjadi sebuah RKA yang memuat seluruh biaya yang diperlukan oleh anak panti selama 1 tahun.
RKA telah selesai dikerjakan akan dikirimkan ke UPT Pelayanan Sosial untuk selanjutnya diserahkan ke Dinas Sosial. Pada Dinas Sosial akan diadakan sidang antara staf Dinas Sosial dan staf panti untuk mempertanggungjawabkan RKA yang telah dibuat oleh staf panti untuk selanjutnya dapat dibuatkan DPA. Sebagai pedoman untuk pengelolaan keuangan di panti. DPA akan diberikan oleh Biro Keuangan kepada Dinas Sosial yang akan diteruskan kepada panti.

Pelaksanaan pengelolaan keuangan di panti dilaksanakan sesuai dengan DPA yang telah diberikan, staf panti selanjutnya akan membuat surat pertanggungjawaban atas pengeluaran yang dilaksanakan sesuai dengan nominal yang tertera di DPA. Surat pertanggungjawaban yang telah terkumpul selama 1 tahun akan diserahkan kepada UPT Pelayanan Sosial dan diteruskan ke Dinas Sosial Provinsi Bali.

Penerapan transparansi di Panti Sosial Asuhan Anak Udyana Wiguna Singaraja dilaksanakan dengan diadakannya rapat setiap triwulan yang membahas mengenai pengelolaan keuangan di panti dan juga mengenai perilaku anak yang terdapat di panti asuhan. Hal ini bertujuan agar seluruh staf panti mengetahui keadaan keuangan yang ada di panti.

\section{Pembahasan}

Berdasarkan hasil penelitian, proses perolehan sumber dana pada Panti Sosial Asuhan Anak dimulai dari dibentuknya RKA (Rancangan Kerja Anggaran) oleh seluruh staf panti asuhan yang selanjutnya akan dikirim ke UPT Pelayanan Sosial untuk dikoreksi dan diserahkan kepada Dinas Sosial Provinsi Bali. Dinas Sosial selanjutnya akan menyerahkan RKA kepada Biro Keuangan Provinsi Bali untuk selanjutnya dibuatkan DPA (Dokumen Pelaksanaan Anggaran) sebagai pedoman untuk pelaksanaan pengelolaan keuangan di PSAA Udyana Wiguna 
Siahaan (2012:72) menyatakan bahwa akuntabilitas adalah kewajiban untuk memberikan pertanggungjawaban dan menerangkan kinerja dan tindakan seseorang/badan hukum/pemimpin suatu organisasi kepada pihak yang memiliki hak atau berkewenangan untuk meminta keterangan atau pertanggungjawaban, meliputi keberhasilan maupun kegagalan pelaksanaan misi instansi yang bersangkutan.

Dalam menjaga akuntabilitasnya, PSAA Udyana Wiguna Singaraja melaksanakan 3 tahapan pelaksanaan yaitu perencaanaan, penyusunan dan pelaksanaan yang benar-benar harus dapat dipertanggungjawabkan kepada pemberi amanah yaitu pemerintah.

Dalam proses perencanaan dan pertanggungjawaban staf panti asuhan mengadakan rapat antara pengurus panti untuk menyusun RKA untuk tahun yang bersangkutan. Selanjutnya setelah RKA selesai disusun oleh staf panti, pada Dinas Sosial akan diadakan sidang kembali antara pengurus panti dan pihak Dinas Sosial untuk diminta pertanggungjawabannya atas RKA yang telah disusun dan disesuaikan dengan pergub.

Pelaksanaan kegiatan di panti disesuaikan dengan DPA yang telah diberikan oleh Dinas Sosial, sebagai bentuk pertanggungjawaban, staf panti akan membuat SPJ untuk masingmasing pengeluaran atas rekening yang terdapat dalam DPA sesuai dengan format yang telah diberikan oleh Dinas Sosial.

Sistem pelayanan di PSAA Udyana

Wiguna Singaraja mudah untuk dipahami dengan adanya petunjuk pelaksanaan teknis pelayanan yang diberikan oleh UPT Pelayanan Sosial sebagai dasar bagi staf panti untuk melaksanakan pelayanan. Staf panti juga menggunakan media sosial berupa facebook untuk mendokumentasikan dan mempublikasikan kegiatan yang dilaksanakan di panti.

Dalam hal pengelolaan keuangan, seluruh staf panti biasanya mengadakan rapat setiap triwulan untuk membahas mengenai keadaan keuangan di PSAA Udyana Wiguna Singaraja. Dengan rapat ini maka seluruh staf panti dapat mengetahui keadaan keuangan yang terdapat di panti sesuai dengan indikator transparansi yaitu kemudahan memperoleh informasi dan keterbukaan pelayaanan. Kemudahan memahami prosedur pengelolaan keuangan sangat mudah dilihat dari pengelolaan keuangan yang dilakukan sesuai dengan DPA yang telah diberikan. Hal ini sejalan dengan yang dikemukakan Dwiyanto (2006:242) dimana ada tiga indikator transparasi yang dapat digunakan.

Indikator pertama adalah mengukur tingkat keterbukaan pelayanan public disini meliputi seluruh proses pelayanan publik, termasuk didalamnya adalah persyaratan, biaya dan waktu yang dibutuhkan untuk suatu pelayanan, serta cara pelayanan. Persyaratan yang harus dipenuhi harus terbuka dan mudah diketahui oleh para pengguna. Penyelenggaraan pelayanan harus berusaha menjelaskan kepada para pengguna mengenai persyaratan yang harus dipenuhi berserta alasan diperlukannya persyaratan itu dalam proses pelayanan.

Indikator yang kedua dari transparasi menunjuk kepada seberapa mudah peraturan dan prosedur pelayanan yang dapat dipahami oleh pengguna dan stakeholder yang lain. Maksud dipahami disini bukan hanya dalam arti literal semata tetapi juga makna dibalik semua prosedur dan peraturan itu. Penjelasan mengenai persyaratan,prosedur,biaya dan waktu yang diperlukan sebagaimana adanya merupakan hal yang paling penting bagi para pengguna. Jika rasionalitas dari semua hal itu dapat diketahui dan diterima oleh para pengguna, maka kepatuhan terhadap prosedur dan aturan akan mudah diwujudkan.

Indikator ketiga dari transparasi adalah kemudahan untuk memperoleh informasi mengenai berbagai aspek penyelenggaraan pelayanan publik. Semakin mudah pengguna memperoleh 
informasi mengenai berbagai aspek penyelenggaraa pelayanan publik semakin tinggi transparasi. Misalnya, ketika pengguna dengan mudah memperoleh informasi mengenai biaya dan waktu yang diperlukan untuk menyelesaikan pelayanan maka pelayanan publik itu dapat dinilai memiliki transparansi yang tinggi.

\section{SIMPULAN DAN SARAN Simpulan}

Berdasarkan hasil dapat disimpukan bahwa proses perolehan dana pada PSAA Udyana Wiguna Singaraja dimulai dari dilaksanakannya analisis kebutuhan anak untuk 1 tahun kedepan, setelah analisis dilaksanakan, maka disusunlah Rancangan Kerja Anggaran oleh staf panti. RKA yang telah disusun akan dikirim ke UPT Pelayanan Sosial Provinsi Bali untuk diteruskan ke Dinas Sosial Provinsi Bali. Pada Dinas Sosial akan diadakan sidang pertanggungjawaban antara staf panti dan staf Dinas Sosial mengenai RKA yang telah disusun. Apabila RKA tersebut disepakati maka staf panti akan menerima Dokumen Pelaksanaan Anggaran. Pengelolaan Keuangan di panti dilaksanakan dengan mengalokasikan biaya untuk masingmasing rekening yang terdapat dalam DPA oleh staf yang mengurus DPA kepada masing-masing staf yang mengurus suatu rekening. Staf yang mengurus rekening akan bertanggungjawab kepada staf yang mengurus DPA. Pertangungjawaban pengelolaan keuangan untuk menjaga akuntabilitas dilaksanakan dimulai dari proses perencanaan dan penyusunan RKA oleh seluruh staf panti yang selanjutnnya akan dilaksanakan sidang antara staf panti dan staf Dinas Sosial untuk mempertanggungjawabkan seluruh RKA yang telah disusun. dan pelaksanaan pengelolaan keuangan yang dilakukan berdasarkan DPA yang telah diberikan oleh Dinas Sosial yang selanjutnya akan dibuatkan SPJ oleh staf panti sebagai bentuk pertanggungjawaban penggunaan dana sesuai dengan nominal yang tertera pada DPA. Transparansi dalam PSAA Udyana Wiguna Singaraja dilihat dari diadakannya rapat yang dilaksanakan setiap triwulan oleh seluruh staf panti yang membahas mengenai pengelolaan keuangan di panti.

\section{Saran}

Adapun saran yang dapat peneliti berikan kepada PSAA Udyana Wiguna Singaraja berdasarkan hasil penelitian adalah agar staf panti membuat struktur organisasi sebagai pedoman untuk staf panti dalam melakukan pekerjaaanya masing-masing. Dengan adanya struktur organisasi, pekerjaan yang dilakukan di panti akan lebih mudah untuk dikoordinir dan mudah untuk dipertanggungjawabkan kepada pemberi amanah dan pihak yang berkepentingan dengan pertanggungjawaban yang dilakukan oleh panti atas penggunaan dana yang telah diberikan.

\section{Daftar Pustaka}

Anggraini, Ristya Dwi 2013. Transparansi, Partisipasi, dan Akuntabilitas Pengelolaan Anggaran Dana BOS Dalam Program RKAS di SDN Pacarkeling VIII Surabaya. Jurnal Kebijakan dan Manajemen Publik, Volume 1, Nomor 24 (hlm.201-208).

Atmaja, dkk. 2013. Teori dan Praktek Manajemen Keuangan. Penerbit Andi: Yogyakarta

Departemen Sosial Republik Indonesia. 2004. Keputusan Menteri Sosial Republik Indonesia No 50/HUK/2004 Tentang Standarisasi Panti Asuhan

Dwiyanto, Agus. 2006. Mewujudkan Good Governance Melalui Pelayanan Publik. Yogyakarta: UGM Press.

Ikatan Akuntan Indonesia. 2004. Peraturan Standar Akuntansi Keuangan No 45 Tentang Organisasi Nirlaba.

Krina P, Lalolo Loina. 2003. "Indikator dan Alat Ukur Prinsip Akuntabilitas, Transparansi dan 
Partisipasi". Tersedia pada https://www.scribd.com/docume nt/25943916/Indikator-Dan-AlatUkur-ATP (diakses tanggal 21 Juli 2017).

Mardiasmo. 2009. Akuntansi Sektor Publik. Yogyakarta: Penerbit Andi.

Siahaan, Marihot Pahala. 2010. Pajak Daerah dan Retribusi Daerah. Jakarta: Raja Grafindo Persada.

Siahaan, Sudin. 2012. Menuju BPK Idaman. Jakarta: PRENADA.

Silvia, J Ansar. 2011. "Akuntabilitas dalam Perspektif Gereja Protestan ( Studi Fenomenologis pada Gereja Protestan Indonesia Donggala Jemaat Manunggal Palu)". Makalah disajikan dalam Simposium Nasional Akuntansi ke 14. Fakultas Ekonomi. Universitas Syiah Kuala, Banda Aceh 21-22 Juli 2011.

Sujarweni, Wiratna. 2015. Akuntansi

Sektor Publik. Yogyakarta:

Pustaka Baru Press. 